九州大学学術情報リポジトリ

Kyushu University Institutional Repository

\title{
On Copepoda of the family Corycaeidae in Japanese waters
}

Tanaka, Otohiko

Fisheries Laboratry, Department of Agriculture, Kyusyu University

https://doi.org/10.5109/22677

出版情報：九州大学大学院農学研究院紀要. 11（1)，pp.77-97，1957-08. Kyushu University バージョン：

権利関係 : 
Journal of the Faculty of Agriculture, Kyūshū University, Vol. 11, No. 1 August 30, 1957

On Copepoda of the family Corycaeidae in Japanese waters

OTOHIKo TANAKA

The species belonging to this family are, for the most part, high sea forms and are met with in the warm waters of oceans. The following six species had been known up until 1937 when Mori recorded fourteen species from the neighbouring waters of Japan. They are $C$. speciosus Dana, C. robustus Giesbrecht, $C$. ovalis Claus, $C$. danae Giesbrecht (C. crassiusculus Dana), C. anglicus Lubbock and C. rostratus Claus. Among these anglicus has been recorded from the European coast of the Atlantic, and the occurrence of this species in the Japanese waters cannot be accepted without further evidence; it is probably identical with the species described by Mori (1937) under the name japonicus. Mori recorded in 1937 the following fourteen species: $C$. lautus Dana, C. speciosus Dana, C. crassiusculus Dana, C. agilis Dana, C. long istylis Dana, C. flaccus Giesbrecht, C. catus F. Dahl, C. latus Dana, C. ovalis Claus, C. asiaticus F. Dahl, C. trukicus Mori, C. gibbulus Giesbrecht, $C$. concinnus Dana and $C$. japonicus Mori. The last species is, as pointed out by Davis (1949), identical with C. affinis McMurrich which is abundant in the northeastern Pacific at certain times of the year. The female specimen of C. trukicus is immature and doubtful; the male specimen of the species is, in my opinion, identical with the male of $C$. andrewsi Farran. Mori's $C$. latus and C. catus appear to be erroneous: the former is identical with $C$. catus F. Dahl, and the latter with C. pacificus F. Dahl.

I have collected twenty-three species from the warm waters of the Pacific coast and the Sea of Japan. They are: C. speciosus, C. clausi F. Dahl, C. crassiusculus, C. viretus Dana, C. robustus Giesbrecht, $C$. typicus Kröyer, $C$. laccus, C. limbatus G. Brady, C. longistylis, $C$. lautus, C. furcifer Claus, C. andrewsi Farran, C. asiaticus F. Dahl, C. subtilis M. Dahl, C. dubius Farran, $C$. dahli nom nov., C. affinis, $C$. 
agilis, C. catus, C. pacificus F. Dahl, C. rostratus Claus, C. gibbulus and $C$. concinnus Dana. Thus the species taken from the adjacent waters of Japan amount to 24 in number.

About fourty-one species of the family Corycaeidae have been reported from the oceans; the following thirteen species from both the Atlantic and Indo-Pacific: C. rostratus, C. gracilis Dana, C. speciosus, C. clausi, C. flaccus, C. limbatus, C. lautus, C. furcifer, C. amazonicus M. Dahl, C. minimus M. Dahl, C. latus, C. giesbrechti F. Dahl and C. ovalis Claus; four species from the Atlantic: C. elongatus Claus, C. africanus F. Dahl, $C$. anglicus Lubbock and $C$. huxleyi Lubbock; the following twenty-four species appear to be of the Indo-Pacific: $C$. carinatus Giesbrecht, C. brevis Farran, C. curtus Farran, C. gibbulus Giesbrecht, C. concinnus, C. crassiusculus, $C$. viretus Dana, C. robustus, C. typicus M. Dahl (C. alatus Giesbrecht), C. longistylis, C. lubbocki Giesbrecht, C. tenuis Giesbrecht, C. asiaticus, C. erythraeus Cleve, C. dubius Farran, C. andrewsi, C. subtilis M. Dahl, C. agilis, C. pacificus, C. catus, C. pumilus M. Dahl, C. medius Gurney, C. brehmi Steuer and C. affinis.

It is interesting to compare the Japanese species with those taken from the other regions of the Pacific, and from the Indian Oceans. The following number of species have been recorded from these regions: eighteen species from the Ceylon Pearl Fishery Bank by Thomson and A. Scott (1903); nine species from Bombay by Cleve (1903); eleven species from the Maldive and Laccadive Archipelago by Wolfenden (1905); sixteen species from the Malay region by A. Scott (1909); twenty species from the Christmas Island, Indian Ocean by Farran (1911); twenty-seven species from the Indo-Pacific by M. Dahl (1912); four species from the Suez Canal by Gurney (1912) ; twenty-four species from the Great Barrier Reef by Farran (1936); eleven species from the Indian Ocean by Sewell (1947); twenty-one species chiefly from the Pacific Ocean by Wilson (1950); two species from the San Diego region by Esterly (1905); one species from the northeastern waters of the North Pacific by Davis (1949). Among these species the following twelve species have not been recorded from the Japanese waters: $C$. erythraeus Cleve, $C$. amazonicus F. Dahl, C brehmi Steuer, C. minimus F. Dahl (C. venustus Dana?), C. medius Gurney, C. pumilus M. Dahl, C. curtus Farran, C. carinatus Giesbrecht and C. pellucidus Dana (C. gracilis Dana?).

It is probable that intensive study of copepoda extends the knowledge on the geographical distribution of the species, but a list of species without description and figures will bring much confusion to the question, and it is never superfluous to give them again. 


\section{Description of the species \\ Genus Corycaeus Dana \\ Subgenus Corycaeus M. Dahl}

Corycaeus (Corycaeus) speciosus Dana

Plate 3, figs. $1-6$

Corycaeus speciosus Giesbrecht, 1892, p. 673, taf. 51, figs. 39, 40.

Corycaeus speciosus A. Scott, 1909, p. 251.

Corycaeus (Corycaeus) speciosus M. Dahl, 1912, p. 13, taf. 1, 2.

Corycaeus speciosus Farran, 1936, p. 134.

Corycaeus speciosus Mori, 1937, p. 133, pl. 72, figs. 9-15.

Corycaeus (Corycaeus) speciosus Sewell, 1947, p. 276.

Corycaeus speciosus Wilson, 1950, p. 196.

Female. Length, $1.86-1.97 \mathrm{~mm}$. Head and 1st thoracic segment partially fused. Posterior corners of 3rd thoracic segment exceed the distal margin of genital segment. Cephalothorax and 2-jointed abdomen in the proportional lengths $14: 9$. Abdominal segments and furcal rami in the proportional lengths calculated in parts per 100 are $38: 16: 46$. Anterior segment, the head and 1st thoracic segment, is about $3 / 5$ as wide as long. Long and divergent furcal rami are the characteristic feature of the species.

Male. Length, $1.481 .62 \mathrm{~mm}$. Head and 1st thoracic segment fused. Proportional lengths of cephalothorax and abdomen 5:4, and those of abdominal segments and furcal rami 33:21:46. Anterior segment is about 1.8 times as long as wide. Genital segment about $3 / 5$ as wide as long (14:9). Anal segment more than 2 times as wide as long, and is of the same width throughout its length. Furcal rami slender, about 12 times as long as wide. Posterior corners of 3rd thoracic segment exceed the middle of the genital segment.

The species is very common in Japanese waters. According to M. Dahl it is widely distributed in the warm regions of the Pacific, Indian and Atlantic Oceans.

\section{Corycaeus (Corycaeus) clausi F. Dahl \\ Plate 3, figs. $7-11$}

Corycaeus ovalis Giesbrecht, 1892 , p. 659 , taf. 51 , figs. 1-3.

Corycaeus (Corycaeus) clausi M. Dahl, 1912, p. 18, taf. 2, figs. 5-12.

Corycaeus clausi Wilson, 1950, p. 193.

Female. Length, $1.50 \mathrm{~mm}$. Cephalothorax, $1.1 \mathrm{~mm}$, abdomen, 0.44 $\mathrm{mm}$. Head fused with 1st thoracic segment. Proportional lengths of abdominal segments and furcal rami $46: 22: 32$. Anterior segment about 1.6 times as long as wide. Genital segment oval, about as wide 
as long (22:23). Anal segment wider at the proximal than at the distal (15:11). Furcal rami more than 3 times as long as it is wide at the proximal. Posterior corners of 3rd thoracic segment extend to the two-thirds of the genital segment.

Male. Length, $1.37 \mathrm{~mm}$. Cephalothorax, $0.85 \mathrm{~mm}$, abdomen, 0.52 $\mathrm{mm}$. Proportional lengths of abdominal segments and furcal rami $46: 21: 33$. Genital segment about 2 times as long as wide $(7: 4)$. Anal segment is by one-fifth wider at the proximal than at the distal $(10: 8)$. Furcal rami about 7 times as long as it is wide at the proximal $(20: 3)$.

The species is very rare in Japanese waters. 'The spcies has been recorded from the temperate waters of the Atlantic, but rarely from the Indo-Pacific.

\section{Corycaeus (Corycaeus) crassiusculus Dana}

Plate 3, figs. $12--15$

Corycaeus danae (Giesbrecht, 1192, p. 660, taf. 51, figs., 59, 60.

Corycaeus (Corycaeus) crassinsculus M. Dahl, 1912, p 21, taf. 3, figs. 1-7.

Corycaeus crassiusculus Farran, 1936, p. 134.

Corycaeus crassiusculus Mori, 1937, p. 133, pl. 75, figs 1-5.

Corycaeus (Corycaeus) crassiusculus Sewell, 1947, p. 272, fig. 69, a-h.

Corycaeus crassiusculus Wilson, 1950, p. 193.

Female. Length, $1.44-1.57 \mathrm{~mm}$. Head separates from 1st thoracic segment. Proportional lengths of cephalothorax and abdomen $21: 11$, and those of abdominal segments and furcal rami $39: 24: 37$. Anterior segment is about 2 times as long as wide (17:9). Genital segment is about 1.3 times as long as wide. Anal segment litlle wider at the proximal than at the distal $(8: 7)$. Distal margin of the genital segment extends on the dorsal surface over the anal segment. Furcal rami about 6 times as long as it is wide at the proximal. Posterior corners of 3rd thoracic segment extend to the distal end of the genital segment.

Male. Length, $1.27-1.36 \mathrm{~mm}$. Head fused with 1st thoracic segment. Proportional lengths of cephalothorax and abdomen 51:31, and those of abdominal segments and furcal rami $40: 21: 39$. Anterior segment about 1.8 times as long as wide (18:9). Genital segment about 1.5 times as long as wide (26:17). Anal segment little wider at the proximal than at the distal $(8: 7)$, and 2 times as long as it is wide at the distal. Furcal rami about 8 times as long as it is wide at the proximal. Posterior corners of 3rd thoracic segment not so slender as in the male of $C$. speciosus, and extend to the middle of the genital segment. 
The species is very common in Japanese waters. It is, according to M. Dahl, widely distributed in the Indo-Pacific Ocean and the Mediterranean Sea.

\section{Corycaeus (Corycaeus) viretus Dana}

Plate 4, figs. 1-4

Corycaeus (Corycaeus) viretus M. Dahl, 1912, p. 25, taf. 3, figs. 8-13.

Corycneus viretus Farran 1936, p. 134, fig. 28, a-d.

Corycaeus viretus Wilson, 1950, p. 197.

Male. Length, $1.55-1.60 \mathrm{~mm}$. Body much more inflated than the foregoing species. Cephalothorax 1.5 times as Iong as abdomen (26: 17). Proportional lengths of abdominal segments and furcal rami 55: $15: 30$. Anal segment is wider at the proximal than at the distal (13: 11 ), and is about as long as it is wide at the distal $(10: 11)$. Furcal rami 5 times as long as wide (19:4).

The species is rare in Japanese waters. Six male specimens were collected from the Pacific coast of Middle-Japan and from the Sea of Japan. It has been recorded from the Indian Ocean near the west coast of Sumatra.

\section{Subgenus Monocorycaeus M. Dahl}

Corycaeus (Monocorycaeus) robustus Giesbrecht

$$
\text { Plate } 4 \text {, figs. } 5-\cdots-8
$$

Corycaeus robustus Giesbrecht, 1892, p. 673 , taf. 51 , figs. 38,42 .

Corycaeus robustus A Scott, 1909, p. 251.

Corycaeus (Monocorycaeus) robustus M. Dahl, 1912, p. 27, taf. 4, figs. 1-8.

Corycaeus robustus Farran, 1936, p. 135.

Corycaeus robustus Wilson, 1950, p. 196.

Female. Length, $2.11 \mathrm{~mm}$. Cephalothorax, $1.38 \mathrm{~mm}$, abdomen 0.73 $\mathrm{mm}$. The species is easily distinguished from the other members of the genus by the robust cephalothorax and genital segment. Proportional lengths of abdominal segments and furcal rami 59:12:29. Genital segment 1.4 times as long as wide $(10: 7)$.

The species is very rare in Japanese waters. Only a single female specimen was collected from the Pacific coast. The species has been recorded from the tropical region of the Pacific.

Subgenus Agetus M. Dahl

Corycaeus (Agetus) typicus Kröyer

Plate 4, figs. 9--15

Corycaeus alatus Giesbrecht, 1892 , p. 674, taf. 51, figs 8,9 . 
Carycaeus (Agetus) typicus M. Dahl, 1912, p 31, taf. 4, figs. 9-14, taf. 5, figs. 1-3. Corycaeus typicus Farran, 1936, p. 135.

Corycaeus typicus Wilson, 1959, p. 196.

Female. Length, $1.50-1.61 \mathrm{~mm}$. Head separates from 1st thoracic segment. Cephalothorax and abdomen in the proportional lengths $2: 1$. Genital segment and furcal rami in the proportional lengths $55: 45$. Inner marginal furcal seta flanged, and longer than the furcal ramus itself. The peculiar form of 4 th thoracic segment and abdomen separate the species from the other members of the genus.

Male. Length, 1.50-1.54 mm. Cephalothorax and abdomen in the proportional lengths $8: 5$. Anterior segment less than 2 times as long as wide $(40: 23)$. Abdominal segments and furcal rami in the proportional lengths $52: 18: 30$. Genital segment about 1.5 times as Iong as wide $(33: 23)$. Anal segment little wider at the proximal than at the distal $(9: 8)$. Furcal rami more than 6 times as long as it is wide at the proximal $(19: 3)$. Terminal claw of 2 nd antenna about 2 times as long as the outer-marginal one arising from the proximal of the apical joint. In the other specimen dissected the claw is much shorter $(3: 2)$, and the spine of 1 st basal joint of 2 nd antenna longer than that of 2 nd basal joint $(4: 3)$, whereas they are of about the same lengths in the ordinary specimen.

The species is fairly common in Japanese waters. Ten females and five males were collected from the Pacific coast. It has been recorded from the Indo-Pacific, the tropical region of the Atlantic and the Mediterranean Sea.

\section{Corycaeus (Agetus) flaccus Giesbrecht \\ Plate 5, figs. $1-7$}

Corycaeus flaccus Giesbrecht, 1892, p. 674, taf. 51, figs. 10, 11.

Corycaeys flaccus A. Scott, 1909, p. 248.

Corycaeus (Agetus) flaccus M. Dahl, 1912, p. 35, taf. 5, figs. 4-11.

Corycaeus flaccus Farran, 1936, p. 135.

Corycaeus flaccus Mori, 1937, p. 135, pl. 73, figs. 7-15.

Corycaeus flaccus Wilson, 1950, p. 193.

Female. Length, $1.56-1.67 \mathrm{~mm}$. Head separates from 1st thoracic segment. Cephalothorax and abdomen in the proportional lengths $9: 4$. Anterior segment 1.8 times as long as wide $(47: 26)$. Abdominal seg. ments and furcal rami in the proportional lengths $4: 3$. Genital segment 1.5 times as long as wide, has a small rounded protuberance on the mid-dorsal of the segment. Lateral margins of genital segment are furnished with short hairs. Inner marginal furcal seta is the longest and is flanged.

Male. Length 1.37-1.39 mm. Cephalothorax and abdomen in the 
proportional lengths 5:3. Anterior segment $3 / 5$ as wide as long. Abdominal segments and furcal rami in the proportional lengths $47: 20$ : 33. Genital segment 1.5 times as long as wide $(29: 19)$; lateral distal margins of the segment produced when viewed from the dorsal. Anal segment wider at the proximal than at the distal $(9: 8)$. Furcal rami 7 times as long as wide $(20: 3)$. Terminal claw of 2 nd antenna about 2.5 times as long as the outer-marginal one arising from the proximal of the apical joint, and about as long as the spines of the basal joints. Inner margin of 2 nd basal joint has no large tooth, but is finely serrated.

The species is rather rare in Japanese waters. Seven females and three males were collected from the Pacific coast, and one male from the Japan Sea. The species is distributed in the warm waters of the Atlantic, especially in the Sargassum Sea, Mediterranean and IndoPacific.

\section{Corycaeus (Agetus) limbatus G. Brady}

Plate 5, figs. 8-12

Corycaeus elongatus Giesbrecht, 1892, p 674, taf. 51, fig. 6 .

Corycaeus (Agetus) limbatus M. Dahl, 1912, p 38, taf. 5, figs. 12-14, taf. 6, figs. 1-5.

Corycaeus limbatus Farran, 1936, p. 136.

Corycaeus limbatus Wilson, 1950 p. 194.

Femalc. Length, $1.36 \mathrm{~mm}$. Cephalothorax, $1.00 \mathrm{~mm}$., abdomen, 0.36 $\mathrm{mm}$. One-jointed abdomen is 2 times as long as furcal rami. The rhomboidal form of genital segment in dorsal aspect is a good specific character of the female.

Male. Length, $1.22 \mathrm{~mm}$. Cephalothorax, $0.77 \mathrm{~mm}$, abdomen, 0.45 Abdominal segments and furcal rami in the proportional lengths 52: $17: 29$. Anterior segment less than 2 times as long as wide (7:4). The large cuticular lenses are contiguous. Genital segment about 1.6 times as long as wide $(27: 17)$. Anal segment is of the same width throughout its length, and 1.5 times as long as wide. Furcal rami 5 times as long as wide. Terminal claw of 2nd antenna about 2.5 times as long as the outer-marginal one.

The species is rare in Japanese waters. Three females and one male were collected from the Pacific coast. The species is distributed in the warm waters of the Atlantic and Indo-Pacific.

\section{Subgenus Urocorycaeus M. Dahl}

Corycaeus (Urocorycaeus) longistylis Dana

Plate 5, figs. $13-16$

Corycaeus longistylis Gieşbrecht, 1892, p. 674, taf. 51, fig. 37. 
Corycaeus (Urocorycaeus) longistylis M. Dahl, 1912, p. 42, taf. 6, 7.

Corycaeus longistylis A. Scott, 1909, p. 249.

Corycaens longistylis Farran, 1936, p. 136.

Corycaeus longistylis Mori, 1937, p. 134, pl. 73, figs. 3-8.

Corycaeus (Urocorycaeus) longistylis Sewell, 1949, p. 277.

Corycaeus longistylis Wilson, 1950, p. 195.

Female. Length, $2.80 \mathrm{~mm}$. Head fused with Ist thoracic segment. Third and fourth thoracic segments completely fused. Cephalothorax little longer than the combined length of abdominal segments and furca. Lateral corners of 3rd thoracic segment produced posteriorly to about the distal $1 / 3$ of genital segment. Abdominal segments and furcal rami in the proportional lengths $21: 21: 58$. Dorsal surface of genital segment vaulted. Furcal ramus slender and long, about 16 times as long as it is wide at the proximal.

Male. Length, 2.13-2.19 mm. Cephalothorax and abdomen in the proportional lengths $31: 29$. Abdominal segment and furcal rami are in the proportional lengths 13:18. Terminal claw of 2 nd antenna about 3 times as long as the proximal outer-marginal one. There is a row of small teeth on the nuter margin and the median line of 2 nd basal joint of 2nd antenna.

The species is fairly common in Japanese waters. One female and fourteen males were collected from the Pacific coast. The species has been recorded only from the Pacific. Mori recorded the species from the southern waters of Japan.

\section{Corycaeus (Urocorycaeus) lautus Dana}

Plate 6, figs. $1-2$

Corycaeus (Urocorycaeus) lautus M. Dahl, 1912, p. 45, taf. 7. figs. 4-14.

Corycaeus lautus Farran, 1936, p. 136.

Corycaeus lautus Mori, 1937, p. 132, pl. 72, tigs. 1-8.

Corycaeus lautus Wilson, 1950, 194.

Male. Length, 2.29-2.32. Cephalothorax and abdomen in the proportional length $31: 33$. Abdominal segments and furcal rami in the proportional lengths $25: 18: 57$. Proximal tooth on the inner distal margin of 2nd basal joint of 2nd antenna very sharp. Process of 2nd basal joint of 4 th leg is furnished, beside a normal long seta, with a short one.

The species is rather rare in Japanese waters. Four males were collected from the Pacific coast. It has been recorded from the Sargassum Sea, the adjacent sea of New Guinea, and Pacific Ocean $\left(113^{\circ} \mathrm{W} 13^{\circ} \mathrm{S}\right)$. Mori collected the species from the southern warm waters of Japan. 


\section{Corycaeus (Urocorycaeus) furcifer Claus}

Plate 6 , figs. $3-6$

Corycaens furcifer Giesbrecht, 1892, p. 674, taf. 51, figs. 41, 44-46.

Corycaeus furcifer A. Scott, 1909, p. 248.

Corycaeus (Urocorycaeus) furcifer M Dahl, 1912, p 48, taf. 8, figs. 1-7.

Corycaeus furcifer Farran, 1936, p. 136.

Corycaeus furcifer Wilson, 1950, p. 193.

Female. Length, $19.2 \mathrm{~mm}$. Cephalothorax, $1.02 \mathrm{~mm}$, abdomen, 0.90 $\mathrm{mm}$. Abdominal segments and furcal rami in the proportional lengths $20: 12: 68$. Lateral processes of 3rd thoracic segment extend to the proximal $1 / 3$ of genital segment. Genital segment has a rounded process on the dorsal surface about the middle. Anal segment has two sharp spines on the dorsal surface at the distal margin.

The species is very rare in Japanese waters. A single female spccimen was collected from the Pacific coast. It has been recorded from the Indo-Pacific, northern coast of South America, Mediterranean and Sargassum Seas.

\section{Subgenus Ditrichocorycaeus M. Dahl}

The species of this subgenus are, as Sewell (1947) pointed out, the most difficult of all copepods to discriminate. According to the key of the species given by M. Dahl they are divided into two. The first group has short furcal rami which are about as long as anal segment but shorter than genital segment; to this group belong $C$. andrewsi, C. asiaticus and C. subtilis M. Dahl. The second group is characterized by the possession of furcal rami which are longer than both anal segment and genital segment; to this group belong C. amazonicus $\mathrm{F}$. Dahl, C. anglicus Lubbock, C. minimus M. Dahl, C. tenuis Giesbrecht, C. lubbocki Giesbrecht, C. africanus F. Dahl, C. dubuis Farran, C. tenuis Farran, C. erythraeus Cleve and C. lubbocki M. Dahl. Among those $C$. lubbocki Giesbrecht, C. tenuis Giesbrecht and C. minimus have no ventral hook on the genital segment in the female. M. Dahl (1912) described from the material taken in Sansibar, Ceylon and the China Sea, the species which had a ventral hook under the name lubbocki, and concluded that C. tenuis Farran is identical with her lubbocki. However, Sewell disagreed with M. Dahl's opinion and states that Giesbrecht's $l u b b o c k i$ which has no ventral hook is not identical with Dahl's lubbocki, and the true lubbocki Giesbrecht was redescribed in 1924 by Früchtl under the name farrani. He further states that tenuis Farran (non Giesbrecht) and lubbocki M. Dahl (non Giesbrecht) are probably synonymous, and both of them are synonymous of $C$. africanus F. Dahl. I have now three species of Ditrichocorycaeus belonging to 
the second group; one of them is, without doubt, identical with tenuis Farran; the other two appear to be dubius Farran and japonicus Mori respectively. The last species is one of the most common one in the warm waters of Japan, and is synonymous, as indicated by Chales $\mathrm{C}$. Davis (1949), with C. affinis McMurrich.

\section{Corycaeus (Ditrichocorycaeus) andrewsi Farran}

Plate 6, figs. 7--12

Corycaeus andrewsi Farran, 1911, p. 294, pl. 13, 14.

Corycaeus (Ditrichocorycaeus) andrewsi M. Dahl, 1912, p. 78, taf. 9, figs. 10-18.

Corycaeus andrewsi Farran, 1936, p. 138

Corycaeus trukicus Mori, 1937, p. 137, pl. 75, figs. 9-16.

Female. Length, $1.00-1.07 \mathrm{~mm}$. Cephalothorax and abdomen in the proportional lengths $2: 1$. Head separates from 1st thoracic segment. Distal corners of 3rd thoracic segment produced into small wing-like expansions. Distal corners of 4 th thoracic segment not extending to the middle of genital segment. Abdominal segments and furcal rami in the proportional lengths $47: 29: 24$. There are two groups of fine hairs on the ventral surface of genital segment when viewed from the lateral, but no ventral hook. Inner marginal spine of 2nd basal joint of 2nd antenna about $3 / 5$ times as long as that of 1 st joint.

Male. Length, 0.820 .88 . Cephalothorax and abdomen in the proportional lengths 29:19. Abdomal segments and furcal rami in the proportional lengths $58: 21: 21$. Anterior segment 1.5 times as long as wide $(42: 27)$. 2nd thoracic segment has on the lateral margins each a slight swelling about the middle. Genital segment $4 / 5$ as wide as long, broadish oval in shape, and has a small ventral hook. Anal segment is of about the same width throughout its length, and 1.5 times as long as wide. Furcal rami 4 times as long as it is wide at the proximal. Wing-shaped expansions of 3rd thoracic segment extend to proximal $1 / 3$ of genital segment. There is a longitudinal median row of spinules on 2nd basal joint of 2nd antenna.

Remarks. Corycaeus trukicus Mori belongs to the subgenus Ditrichocorycaeus. His female specimen has coarsely plumosed spines on each of the 1st and 2nd basal joints of 2nd antenna; this is a characteristic feature of the immature specimen of Corycaeus (sensu lato) except the subgenus Corycella Farran. C. trukicus is closely allied to $C$. andrewsi, C. asialicus, and $C$. subtilis in having short furcal rami which are about as long as anal segment. His specimens measured $0.65-0.95 \mathrm{~mm}$ in female, and $0.8 \mathrm{~mm}$ in male. The female specimens deviate too much in total length. The smallest species among Ditrichocorycaeus is, according to M. Dahl, C. sublilis M. Dahl which measures $0.75-0.77 \mathrm{~mm}$ in female. C. trukicus differs from $C$. 
subtilis in having a prolonged 4th thoracic segment, and a long plumose spine on the 2nd basal joint of 2nd antenna. The male specimen of C. trukicus agrees fairly well with the male of $C$. andrewsi in having furcal rami which are about as long as anal segment, and in having short wing-like expansions on the 3rd thoracic segment. My male specimen has on the lateral margins of 2nd thoracic segment a slight swelling on each side about the middle. This is clearly illustrated by Mori in his figure of the male specimen of trukicus.

This is one of the most common species in Japanese waters. Ten females and sixteen males were collected from the Pacific coast. The species has been recorded from the Indo-Pacific Ocean. Mori recorded the occurrence of the species from the station near Truk Island.

\section{Corycaeus (Ditrichocorycaeus) asiaticus F. Dahl}

Plate 6, figs. 13-19

Corycaens murrayi Farran, 1911, p. 294, pl. 13, figs. 1-6.

Corycaeus (Ditrichocorycaeus) asiaticus M. Dahl, 1912, p. 74, taf. 11, figs. 1-9.

Corycaeus asiaticus Gurney, 1926, p. 163 fig. 24, a-c.

Corycaeus asiaticus Farran, 1936, p. 137.

Corycaeus asiaticus Mori, 1937, p. 136, pl. 75, figs. 6-8.

Corycaeus (Ditrichocorycaeus) asiaticus Sewell, 1947, p. 281.

Female. Length, $1.15-1.19 \mathrm{~mm}$. Cephalothorax and abdomen in the proportional lengths $15: 8$. Anterior segment 1.6 times as long as wide. Abdominal segments and furcal rami in the proportional lengths $42: 29: 29$. Genital segment about as long as wide $(20: 28)$, has no ventral hook; proximal ventral corner of the segment rectangular. Anal segment about as long as it is wide at the proximal (14:12); the proximal margin of segment 1.5 times as wide as it is wide at the proximal $(12: 8)$. Furcal rami 5 times as long as wide $(14: 3)$. Distal margin of 2 nd basal joint of 2nd antenna has a small tooth distal to the large one. Apical spine of exopodite of 2 nd leg is curved and without peculiar serration.

Male. Length, $1.04-1.12 \mathrm{~mm}$. Cephalothorax and abdomen in the proportional lengths $3: 2$. Anterior segment 1.6 times as long as wide (14:9). Wing-like expansions of 3rd thoracic segment extend posteriorly about to the middle of genital segment. Abdominal segments and furcal rami in the proportional lengths $49: 24: 27$. Genital segment 1.3 times as long as wide $(23: 18)$. Anal segment is of the same width throughout its length, and about 2 times as long as it is wide at proximal. Furcal rami about 6 times as long as it is wide at the middle of the ramus $(25: 4)$. Ventral hook of genital segment shows some individual difference.

The species is rather rare in Japanese waters. Four females and 
three males were collected from the Pacific coast and one female from the Sea of Japan. It has been recorded from the Indo-Pacific.

\section{Corycaeus (Ditrichocorycaeus) subtilis M. Dahl}

Plate 7 , figs. $1-4$

Corycaeus (Ditrichocorycaens) subtilis M. Dahl, 1912, p. 80, taf. 8, figs. 9-16.

Corycaeus subtilis Farran, 1936 , p. 138.

Corycaeus subtilis Wilson, 1950, p. 196.

Female. Length, $0.76 \mathrm{~mm}$. Cephalothorax, $0.52 \mathrm{~mm}$, abdomen, 0.24 $\mathrm{mm}$. Abdominal segments and furcal rami in the proportional lengths $44: 26: 30$. Wing-like cxpansions of 3rd thoracic segment not extending to the middle of genital segment. Processes of posterior corners of 4th thoracic segment very small. Apical spine of exopodite of 2nd leg has two teeth on the inner anterior side.

The species is very rare in Japanese waters. Two females were collected from the Pacific coast. It has been recorded from the IndoPacific.

\section{Corycaeus (Ditrichocorycaeus) dubius Farran}

$$
\text { Plate } 7 \text {, figs. } 5-13
$$

Corycaeus dubius Farran, 1911, p. 292, pl. 12, 14.

Corycaeus (Ditrichocorycaeus) dubius M. Dahl, 1912, p. 71, taf. 10, figs. 11-19.

Corycaeus erythraeus Gurney, 1926, p. 161, fig. 23, a-d.

Corycaeus erythraeus Farran, 1936, p. 137.

Corycaeus dubius Wilson, p. 193.

Female. Length, $109 \mathrm{~mm}$. Cephalothorax, $0.65 \mathrm{~mm}$, abdomen, 0.44 $\mathrm{mm}$, so the abdomen is contained about 5 times in the length of the cephalothorax. Cephalothorax rather slender, about 2.4 times as long as wide (90:38). Head separates from thoracic segment. Posterior corners of 3rd thoracic segment exceed slightly beyond the middle of genital segment. 4th thoracic segment short, with sharp points. Proportional lengths of abdominal segments and furca measured ventrally $31: 33: 36$; another specimen measuring $1.04 \mathrm{~mm}$ in overall length has the proportional length $29: 35: 36$. Genital segment about 1.3 times as Iong as wide with a sharp hook directing posteriorly at the proximal corner of the segment when viewed from the lateral. The sides of 2nd abdominal segment parallel, about 2.5 times as long as wide. Furcal rami slightly divergent, 10 times as long as wide. The spine arising from 2nd basal joint of 2nd antenna slightly less than $1 / 3$ the length of that from 1st basal joint, reaches the middle of the joint. Apical spine of exopodite of 2 nd leg has about 5 teeth on the inner anterior side. 
Male. Length, $0.836 \mathrm{~mm}$. Cephalothorax, $0.45 \mathrm{~mm}$, abdomen, 0.386 $\mathrm{mm}$, so the abdomen is contained 1.2 times in the length of cephalothorax. Posterior corners of 3rd thoracic segment do not extend to the middle of genital segment. Abdominal segments and furcal rami in the proportional lengths $39: 26: 35$. This proportion differs slightly from those given by $M$. Dahl $(40.3: 24.2: 35.5)$ or Gurney $(41.8: 24.0: 34.2)$. Teeth on the inner distal margin of 2 nd basal joint of 2 nd antenna stronger than those figured by M. Dahl. The characteristic teeth on the inner anterior side of the apical spine of the exopodite of 2nd leg not observed in the male specimen.

The species is rare in Japanese waters. A single male from the Pacific coast and two females from the Sea of Japan. The species has been recorded from the tropical regions of the Pacific and Indian Oceans, and also from the Suez Canal.

Remarks. The present specimen, though slightly larger in size than those of Farran (female $0.97 \mathrm{~mm}$, from Christmas Island; female $0.96-1.02 \mathrm{~mm}$, male $0.84-0.91 \mathrm{~mm}$ from the Great Barrier Reef), agrees quite well with his description and figures of C. dubius. Gurney (1927, p. 161) states that his erythraeus collected from the Suez Canal are probably be identical with erythraeus Cleve taken from the Red Sea. Farran (1936, p. 137), regarding Gurney's identification as correct, is of opinion that his dubius is identical with erythraeus Cleve. I agree that erythraeus Gurney is a synonym of dubius Farran, as both specimens have the similar structure in the 2nd antenna. It seems probable that these species may be synonymous but one cannot prove it until the doubtful species, erythraeus Cleve will be more fully described.

\section{Corycaeus (Ditrichocorycaeus) dahli sp. nov.}

Plate 7 , figs. 14- 17 , Plate 8, figs. $1-5$

Corycaeus (Ditrichocorycaeus) lubbocki M. Dahl, 1912, p. 64, taf. 10, figs. 20-28.

Corycaens tenuis Farran, 1911, p. 291, p1. 12, figs. 8-9.

Corycaeus (I)itrichocorycaeus) africanus Sewell, 1947, p. 279, text-fig. 70, a-d.

Female. Length, $1.03-1.08 \mathrm{~mm}$. Cephalothorax about 1.7 times as long as abdomen (68:40). Abdominal segments and furcal rami in the proportional lengths $35: 23: 42$. Anterior segment 1.83 time as long as wide $(53: 29)$. Posterior corners of 3rd thoracic segment extend beyond the middle of genital segment. Fourth thoracic segment produced into short pointed processes. Genital segment about 1.3 times as long as wide; dorsal surface of the segment vaulted; there is a folding on the distal $2 / 3$ of the dorsal surface; the ventral surface rather flat. Anal segment wider at the proximal than at the distal, and is 2.6 times as long as it is wide at the distal. Furca divergent, 
about 16 times as long as it is wide at the distal. The spine arising from 1st basal joint of 2nd antenna 2 times as long as that from 2nd basal. Apical spine of exopodite of 2nd leg curved, and has about 6 teeth on the inner anterior side.

Male. Length, $0.89-0.91 \mathrm{~mm}$. Abdomen is contained 1.4 times in the length of cephalothorax $(57: 41)$. Cephalothorax 1.5 times as long as wide $(19: 12.5)$. Propotional lengths of abdominal segments and furcal rami $50: 18: 32$. Genital segment oval in shape, 1.6 times as long as wide (35:21); ventral surface of the segment has a small median hook; cylindrical part of the segment about 1.5 times as long as it is wide at the proximal (14:9). Furcal rami 8 times as long as wide (25:3); the longest furcal seta longer than the furcal ramus itself. In 2nd antenna terminal claw is longer than 2nd basal joint, and 3 times as long as proximal hook of terminal joints; spine arising from 1st basal joint of 2nd antenna little longer than that of 2nd joint. Apical spines of exopodite of the first three legs are straight. Outeredge spine of 3rd joint of exopodite of 4th leg longer than half the length of 3rd joint $(3: 4)$; outeredge spine of 1 st joint of exopodite about half as long as 1st joint of the same leg.

Remark. Nine species of Ditrichocorycaeus have been reported which resemble each other so closely that considerable confusion has arisen in regarding the species. They are $C$. lubbocki Giesbrecht, $C$. lubbocki M. Dahl, C. lubbocki Sewell, C. tenuis Giesbrecht, C. tenuis Farran, C. tenuis M. Dahl, C. africanus F. Dahl, C. africanus Sewell and $C$. brehmi Steuer. Proportional lengths of abdominal segments and furca of the species in parts per 100 as follows:

\begin{tabular}{lcccc}
\hline & Total length mm. & Genital & 2nd & Furcal ramus \\
C. lubbocki Giesbrecht & 0.95 & 37 & 17 & 46 \\
C. lubbocki Seweil & 1.033 & 37.2 & 15.2 & 47.6 \\
C. lubbocki M. Dahl & $0.95-0.97$ & 35.2 & 22.5 & 42.3 \\
C. tenuis Giesbrecht & 0.87 & 37 & 21 & 42 \\
C. tenuis Farran & 1.05 & 35 & 20 & 45 \\
C. tenuis M. Dahl & $0.81-0.84$ & 34.5 & 22.4 & 43.1 \\
C. africanus M. Dahl & $1.01-1.03$ & 37.5 & 18.75 & 43.75 \\
C. africanus Sewell & - & 35.5 & 22.1 & 42.4 \\
C. brehmi & $0.95-1.10$ & 41.8 & 18.6 & 39.6 \\
Present specimens & $1.03-1.08$ & 35 & 23 & 42 \\
\hline
\end{tabular}

Putting aside lubbocki Giesbrecht, tenuis Giesbrecht and lubbocki Sewell which have no ventral hook, and $C$. brehmi, the remaining five have no remarkable difference between them. It is clear that $C$. lubbocki M. Dahl is, according to the description and figures given by both 
Giesbrecht and Sewell (1947, p. 281), not identical with C. lubbocki Giesbrecht. M. Dahl's lubbocki is, as she states, the synonym of $C$. tenuis Farran. Sewell described a form which was taken from the Indian Ocean, and referred it to $C$. africanus F. Dahl. However, his specimen is more closely allied to $C$. lubbocki M. Dahl than to africanus in having the abdominal segments and furcal rami which are nearer in the proportional lengths to those of lubbocki M. Dahl. Moreover, the spine of 1st basal joint of 2nd antenna is, according to Sewell's figure, less than 3 times the length of that of the 2nd basal joint, whereas it is 3 times in africanus. It is probable that lubbocki $\mathrm{M}$. Dahl and tenuis Farran are, as M. Dahl pointed out, synonymous. Sewell is of opinion that both tenuis Farran and lubbocki M. Dahl are synonyms of africanus, but it seems to me that he is not correct. $C$. africanus differs from those two forms not only in the proportional lengths of the abdomen, but also in its geographical distribution. Sewell's record of africanus from the Indo-Pacific seems to be a conjecture. He was forced to choose one of these species, tenuis, lubbocki and africanus. Consequently, he picked up africamus which had been recorded from the west coast of Africa, and referred his specimen to it. His single specimen agrees, as he states, with tenuis Farran. The present specimen comes near to lubbocki M. Dahl, tenuis Farran and africamus Sewell in the proportional lengths of abdominal segments and furca, also in the total lengths. But I am not sure that the specimen is quite identical with the latter three species, as no mention has been made by the authors on the possession of the serration along the inner anterior side of the apical spine of exopodite of 2 nd leg. This serration is apt to be overlooked when it is wrongly situated under microscope. For instance, two figures of the same apical spine viewed in two different aspects are given (plate V, fig. 17); it is easily overlooked when laid as shown in fig. 17, left. I have detected such serration in $C$. dubius Farran, the present specimen and $C$. affinis. The serration appears to be a characteristic feature of some of the female specimens of Ditrichocorycaeus. In my opinion, lubbocki M. Dahl, tenuis Farran and africanus Sewell and the present specimen are synonymous. Here I propose, to avoid further confusion, and to give a new name dahli to the specimen which has the characteristics as shown in the descriptive note. I wished the name farrani, but the name had been reoccupied by Friichtl. Dr. A. Fleminger of Harvard University has recently sent me specimens of Corycaeus (Ditrichocorycaeus) americanus taken from the Gulf of Mexico which appears to be new to science. The female specimen have total lengths 1.12-1.31 $\mathrm{mm}$; abdominal segments and furcal rami in the proportional lengths $28: 15: 57$. The species is characterized by its long furcal rami. The male specimen measured $0.90-1.01 \mathrm{~mm}$ in total length. 
The species is rather rare in Japanese waters. Four females and eight males were collected from the Sea of Japan, and three males from the Pacific coast. It has been recorded from the tropical regions of the Pacific and Indian Oceans, also from the Great Barrier Reef Sea.

\section{Corycaeus (Ditrichocorycaeus) affinis McMurrich}

Plate 8, figs. 6- -15

Corycaeus japonicus Mori, 1937. p. 138, pl. 76, figs. 1-11.

Corycaens affinis Davis, 1949, p, 75, figs. 179-183.

Female. Length, $1.01-1.25 \mathrm{~mm}$. Proportional lengths of cephalothorax and abdomen $77: 43$, and those of abdominal segments and furcal rami $36: 26: 38$. Anterior segment 1.8 times as long as wide $(31: 27)$. Genital segment $3 / 4$ as wide as long. Anal segment little wider at the proximal, and less than 2 times as long as it is wide at the distal (11:6). Furcal rami 1.7 times as long as anal segment (17: 10 ), and about 9 times as long as at is wide at the proximal (17:2); the rami divergent. Dorsal surface of genital segment vaulted, and the vaulted portion is slightly folded between the genital flaps; ventral surface of genital segment produced prominently below at the middle. In 2nd antenna 2nd basal joint 2 times as $10 n g$ as wide; spine arising from 1st basal joint 3 times as long as that from 2nd basal. Apical spine of exopodite of 2nd leg rather straight, has two or sometimes three teeth on the inner anterior side. Outer-edge spine of 3rd joint of exopodite of 4th leg longer than half the length of the joint itself; outer edge spine of 1 st joint of exopodite shorter than half the length of the joint.

Male. Length, $0.83 \mathrm{~mm}$. Cephalothorax 1.6 times as long as abdomen $(51: 38)$. Proportional lengths of abdominal segments and furcal rami $50: 22: 28$. Eyes separated by about $1 / 3$ the greatest diameter. Anterior segment about half the total length of body, $3 / 5$ as wide as long $(31: 50)$. 3rd thoracic segment has sharp backward pointing wings which extend to proximal $1 / 3$ of the genital segment. The demarcation between 3rd and 4th thoracic segments indistinct. 4th thoracic segment produced into small pointed processes. Genital segment 1.7 times as long as wide $(20: 12)$; ventral surface of the segment furnished with a ventrally pointing hook; cylindrical part of the segment about $1 / 3$ the length of the distal margin of the segment. Anal segment 1.6 times as long as it is wide at the distal $(8: 5)$. Furcal rami straight, are of about equal width throughout its length; they are about 6 times as long as wide $(11: 2)$; the longest seta is about twice as long as furcal ramus $(19: 11)$. Inner margin of 2 nd basal joint of and antenna furnished with two teeth, one of which very strong; outer 
margin of 2nd basal joint is furnished with fine teeth; the anterior surface is also furnished with a row of very fine teeth. Spine arising from 1st basal joint of 2nd antenna 5/4 as long as that from 2 nd basal which is furnished with fine hairs. Apical spine of exopodite of 1st leg curved outwardly; that of 2nd leg also curved, and is shorter than that of 3rd leg. Apical spine of exopodite of 3rd leg is straight, and is longer than the 3rd joint of exopodite. 4th leg has two setae on the process of 2nd basal joint; outer-edge spine of 1 st joint of exopodite $2 / 3$ the length of the 1 st joint, and shorter than that of 3rd joint of exopodite which is about as long as the 3rd joint itself.

Remarks. The present female specimen is closely allied to the foregoing species in its general appearance. However, it differs from dahli in the proportional lengths of abdominal segments and furcal rami, namely furcal rami are much shorter in the present specimen. Apical spine of expodite of 2 nd $\mathrm{leg}$ is straight, and the teeth of inner anterior side is less in number. The male specimen has the abdomen which differs also in the proportional lengths from those of dahli.

C. Davis states that japonicus Mori is identical with affinis McMurrich (1916) which is abundant in the waters near Friday Harbor, Washington at certain times of the year. According to his description the proportional lengths of abdominal segment and furcal rami of female are $10: 6: 10(38.4: 23.2: 38.4-100)$; genital segment is as long as furcal ramus. Mori does not mention the proportional lengths of abdominal segments and furca of the female but his figure illustrates that the proportional lengths measured dorsally are $38: 24: 38$, which come very near to my measurements; the genital segment has a folding on the dorsal surface. Thus these characteristics of a female specimen of japonicus agree well with those of $C$. affinis described by Davis. The male specimen of japonicus has the abdomen quite similar in proportional lengths to those of affnis. Mori's specimens measured about $1.1 \mathrm{~mm}$ in female, and $0.9 \mathrm{~mm}$ in male. Davis's measured $1.1 \mathrm{~mm}$ in fcmale, $0.82-0.9 \mathrm{~mm}$ in male. C. anglicus Lubbock which has been recorded by some of the Japanese authors from the Japanese waters is probably identical with the present species.

The species is the most common one in the warm waters of Japan. It appears to have a wide distribution in the North Pacific, and has been recurded from the east and west coasts of Vancouver Island, Friday Harbor, Washington. It has been recorded by Mori from southern waters of the Pacific coast, and from the Inland Sea, and also from the Sea of Japan. I have detected the species from both the Pacific coast and from the Sea of Japan. 


\section{Subgenus Onychocorycaeus M. Dahl \\ Corycaeus (Onychocorycaeus) agilis Dana \\ Plate 8 , figs. $16-18$, Plate 9, figs. $1-5$}

Corycaeus gracilicaudatus Giesbrecht, 1892, p. 674, taf. 51, figs. 15, 30.

Corycaeus (Onychocorycaeus) agilis M. Dahl, 1912, p. 84, taf. 12.

Corycaeus agilis Farran, 1936, p. 138.

Corycaeus agilis Mori, 1937, p. 72, figs. 1-2.

Corycaeus (Onychocorycaeus) agilis Sewell, 1947, p. 284.

Corycaeus agilis Wilson, 1950, p. 192.

Female. Length, $0.88-1.00 \mathrm{~mm}$. Cephalothorax robust, 1.5 times as long as abdomen. Abdominal segments and furcal rami slender, has proportional lengths $35: 28: 36$.

Male. Length, $0.71-0.74 \mathrm{~mm}$. Cephalothorax and abdomen in proportional lengths $47: 36$. Abdominal segments and furcal rami in proportional lengths $40: 27: 33$. Genital segment is in the oval part $3 / 4$ as wide as long. Some specimens had each a minute median hook on the ventral proximal corner of genital segment. The specimen from the Japan Sea measured $1.04 \mathrm{~mm}$ in female, and $0.79 \cdot 0.81 \mathrm{~mm}$ in male.

The species is widely distributed in the warm waters of Japan, and has been recorded from the tropical regions of the Atlantic, Pacific and Indian Oceans.

\section{Corycaeus (Onychocorycaeus) catus F. Dahl}

Plate 9, figs. $6-12$

Corycaeus obtusus Giesbrecht, 1892, p. 673, taf. 51, figs. 12-14.

Corycaeus catus Farran, 1911, p. 290, pl. 12, figs. 1-3.

Corycaeus (Onychocosycaens) catus M. Dahl, 1912, p. 99, taf. 13, figs. 17-24.

Corycaeus catus Farran, 1936, p. 138.

Corycaeus latus Mori, 1937, p. 136, pl. 74, figs. 8-10.

Corycaeus (Onychorycaeus) catus Sewell, 1947, p. 284.

Corycaeus catus Wilson, 1950, p. 192.

Female. Length, $0.93-1.00 \mathrm{~mm}$. Body robust. Abdomen is contained more than 2 times in the length of cephalothorax (9:4). Abdominal segments and furcal rami in the proportional lengths $58: 20: 22$. Anal segment shorter than it is wide at the proximal (7:8). Furcal rami about 4 times as long as wide $(14: 4)$. Outer-edge spine of 1 st joint of exopodite of 4 th leg long, and exceeds the proximal end of 2nd joint; outer edge spine of 3rd joint is about as long as the 3rd joint of exopodite.

Male. Length, $0.80-0.90 \mathrm{~mm}$. Head separates from 1st thoracic segment. Abdomen is contained 1.5 times in the length of cephalothorax (60:38). Abdominal segments and furcal rami in the proportional lengths $59: 19: 22$. Genital segment has a ventral median hook. 
Apical spine of exopodite of 2nd leg is straight but curved slightly inwards near the distal end, and the serrated outer margin is continued towards the inner margin near the apex.

Mori's latus is identical with the present species in having similar proportional lengths in abdominal segments and furcal rami, and the slender wing-like expansion of 4 th thoracic segment in the female. His male specimen of $C$. latus has also general resemblance to the male specimen of $C$. catus $F$. Dahl in the total length and also in the proportional lengths of abdominal segments and furcal rami.

The species is very common in the warm waters of Japan. It has been recorded from the Indo-Pacific Ocean, Great Barrier Reef Sea, and Arabian Sea.

\section{Corycaeus (Onychocorycaeus) pacificus F. Dahl}

\section{Plate 9, figs. 13-29}

Corycaeus (Onychocorycaeus) pacificus M. Dahl, 1912, p. 103, taf. 14.

Corycaeus pacificus Farran, 1936, p. 139.

Corycaeus catus Mori, 1937, p. 74, figs. 1-7.

Corycaeus (Onychocorycaeus) pacificus Sewell, 1947, p. 285.

Corycaeus pacificus Wiison, 1950 , p. 195.

Femaie. Length, $1.12-1.21 \mathrm{~mm}$. Cephaiothorax robust. Abdomen is contained about 2 times in the length of cephalothorax (88:42). Third thoracic segment is very wide; posterior corners of the segment extend to $3 / 4$ of the genital segment. Wings of 4 th thoracic segment short and biuntly pointed. Abdominal segments and furcal rami in the proportional lengths $56: 22: 22$. Genital segment 1.4 times as long as wide $(24: 17)$. Anal segment wider at the proximal than at the distal (2:6), and as long as it is wide at the proximal (9:8). Furcal ranil aboui 5 times as long as wide (9:2). Apical spine of exopodite of 2 nd leg straight, and has an isolated tooth on the inner margin near the apical portion.

Male. Length, $0.99-1.09 \mathrm{~mm}$. Abdomen is contained 1.2 times in the length of the cephalothorax $(64: 46)$. Atudominal segments and furcal rami in the proportional lengths 54:21:25. Genital segment oval, and 1.5 times as long as wide $(26: 17)$. Anal segment about 2 times as long as wide $(11: 6)$. Furcal rami 8 times as long as wide (12:1.5). Genital segment is devoid of ventral hook.

Mori's catus is clearly identical with C. pacificus; his female specimen of catus has narrowly rounded forehaed and large wing-like expansions on the 3rd thoracic segment extending beyond the middle of the genital segment. His male specimen of catus differs from mine in having a ventral hook on the genital segment, and also in the proportional lengths of the abdominal segments and furcal rami. 
The species is very common in Japanese waters. The species has a wide distribution in the Pacific and Indian oceans.

\section{Subgenus Corycella Farran}

Corycaeus (Corycella) rostratus (Claus)

Corycaeus rostratus Giesbrecht, 1892, p. 674, taf. 5, 9.

Corycaeus rostratus Thompson and A. Scott, 1903, p. 285.

Corycaens rostratus Steuer, 1910, p. 31.

Corycaeus (Corycella) rostratus M. Dahl, 1912, p. 111, taf. 5.

Male. Length, $0.69 \mathrm{~mm}$. Cephalothorax, $0.44 \mathrm{~mm}$, abdomen, 0.25 mm. Genital segment $1 / 3$ as wide as long. Furcal rami 3 times as long as wide.

The species is very rare. A single male specimen was collected from the Pacific coast. The species is distributed in the subtropical regions of the Pacific and Atlantic Oceans, also in the Mediterranean Sea.

\section{Corycaeus (Corycella) gibbulus (Giesbrecht)}

Corycaeus gibbulus Giesbrecht, 1892, p. 675, taf. 51.

Corycaeus gibbulus Thompson and A. Scott, 1903, p. 286.

Corycaeus (Corycella) gibbulus M. Dahl, 1912, p. 115, taf. 15.

Corycella gibbula Farran, 1936, p. 139.

Corycaeus gibbulus Mori, 1937, p. 137, pl. 76, figs. 12-16, pl. 77, figs. 1-4.

Female. Length, $0.85-1.00 \mathrm{~mm}$. Cephalothorax, 0.62-0.67 mm, abdomen, $0.27-0.30 \mathrm{~mm}$. The species can be easily recognized by the peculiar form of genital segment.

Male. The male specimen of $C$. gibbulus and C. concinnus differ, as M. Dahl states, only in size. I follow Dahl's suggestion and decide the larger specimen $(0.800 .87 \mathrm{~mm})$ as the male of C. gibbulus, and the small one $(0.73-0.78 \mathrm{~mm})$ as $C$. concinnus.

The species is very common in Japanese waters. It has a wide distribution in the warm regions of the Indian Ocean.

\section{Corycaeus (Corycella) concinnus (Dana)}

Corycaeus concinuus Giesbrecht, 1892, p. 675, taf. 51, figs. 21-24.

Corybaeus concinnus Thompson and A. Scott, 1903, p. 286.

Corycaeus concinnus A. Scott, 1909, p. 246.

Corycaeus (Corycella) concinnus M. Dahl, 1912, p. 121, taf. 15.

Corycella concinna Farran, 1936, p. 139.

Corycaeus concinnus Mori, 1937, p. 138, pl. 77, figs. 5-12.

Female. Length, $0.84-0.90 \mathrm{~mm}$. The present specimen agrees quite well with Dahl's description.

The species is very common in Japanese waters. It is distributed in the subtropical region of the Indian and Pacific Oceans. 


\section{REFERENCES}

Dahl, F. 1894. Ueber die horizontale Verbreitung der Copepoden im Ozean. Verhandl. Deutsch. Zool. Ges. München, Vol. 4, pp. 61-80.

Dahl, M. 1912. Die Corycaeinen. Mit Berücksichtigung aller bekannten Arten. Die Copepoden der Plankton-Expedition. Ergebnisse der Humboldt-Stiftung. Bd. II.

Davis, Chales C. 1949. The pelagic Copepoda of the Northeastern Pacific Ocean. Univ. Washington Publ. Biol. Vol. 14, pp. 1-118.

Esterly, C. O. 1905. The pelagic Copepoda of the San Diego region. Univ. California Publ. Vol. II, No. 4.

Farran, G. P. 1911. Plankton from Christmas Island Indian Ocean. On Copepoda of the family Corycaeidae. Proc. Zool. Soc. London.

Farran, G. P. 1929. Crustacea Pt. X. Copepoda, British Antarctic (Terra Nova) Expedition, 1911. Natural History Report. Zoology Vol. VIII, No. 3.

Farran, G. P. 1936. Copepoda of the Great Barrier Reef Expedition.

Giesbrecht, W. 1892. Pelagischen Copepoden. Fauna und Flora des Golfes von Neapel. Vol. XIX.

Gurney, R. 1926. Crustacea: Copeporla and Cladocera of the Plankton. Cambridge Expedition to Suez Canal, 1924. Trans. Zool. Soc. London.

Klevenhusen, W. 1933. Beitrag zur Systematik und Biologie der Corycaeen nach dem Material der Meteror Expedition. Zool. Jahrb. Syst. 64 (6).

Mori, T. 1937. The Pelagic Copepoda from the Neighbouring Waters of Japan. Tokyo.

Scott, A. 1909. Copepoda of the Siboga Expedition. Monograph, XXIV.

Sewell, R. B. 1947. The free-swimming planktonic copepoda. Systematic Account. John Murray Expedition, 1933-34.

Steuer, A. 1910. Adriatische Planktoncopepoden. Sitzungsberichten der kaisel. Akademie Wissenschaften im Wien. Mathem.-naturw. Klasse. Bd. CXIX, Abt. 1.

Thompson, I. C. and A. Scott. 1903. Report on the Copepoda. Ceylon Pearl Oyster Fisheries; Supplementary Reports. No. VII.

Wilson, C. B. 1950. Copepods gathered by the United States Fishereis Steamer "Albatross" from 1887 to 1909, chiefly in the Pacific Ocean. 


\section{Explanation of Plates}

Plate 3.

Figs, 1-6. Corycaeus (Corycaeus) speciosus Dana

Fig. 1. Female, dorsal view. $\times 30$

Fig. 2. Female, abdomen, lateral view. $\times 60$

Fig. 3. Female, 2nd antenna. $\times 120$

Fig, 4. Female, 4th leg. $\times 120$

Fig. 5. Male, dorsal view. $\times 30$

Fig. 6. Male, 2nd antenna. $\times 120$

Figs. 7-11. Corycaeus (Corycaeus) clausi F. Dahl

Fig. 7. Female, dorsal view. $\times 30$

Fig. 8. Female, abdomen, lateral view. $\times 60$

Fig. 9. Female, 2nd antenna. $\times 173$

Fig. 10. Female, 4th leg. $\times 173$

Fig. 11. Male, dorsal view. $\times 30$

Figs. 12-14. Corycaeus (Corycaeus) crassiusculus Dana

Fig. 12. Female, dorsal view. $\times 30$

Fig. 13. Female, abdomen, lateral view. $\times 60$

Fig. 14. Female, 2nd antenna. $\times 120$

Fig. 15. Male, dotsal view, $\times 30$

Plate 4.

Figs. 1-4. Corycaeus (Corycaeus) viretus Dana

Fig. 1. Male, dorsal view. $\times 30$

Fig. 2. Male, lateral view. $\times 30$

Fig. 3. Male, 2nd antenna. $\times 120$

Fig. 4. Male, 4th leg. $\times 173$

Figs. 5-8. Corycaeus (Monocorycaeus) robustus Giesbrecht

Fig. 5. Female, dorsal view. $\times 26$

Fig. 6. Female, abdomen, lateral view. $\times 30$

Fig. 7. Female, 2nd antenna. $\times 90$

Fig. 8. Female, 4th leg. $\times 120$

\section{Figs. 9-15. Corycaeus (Agetus) typicus Kröyer}

Fig. 9. Female, dorsal view, $\times 30$

Fig. 10. Female, lateral view. $\times 30$

Fig. 11. Female, 2nd antenna. $\times 120$

Fig. 12. Female, 4th leg. $\times 173$.

Fig. 13. Male, dorsal view, $\times 30$

Fig. 14. Male, abdomen, lateral view. $\times 60$

Fig. 15. Male, 2nd anțenna, $\times 173$ 


\section{Plate 5.}

Figs. 1-7. Corycaeus (Agetus) flaccuss Giesbrecht

Fig. 1. Female, lateral view. $\times 30$

Fig. 2. Female, dorsal view. $\times 30$

Fig. 3. Female, 2nd natenna. $\times 120$

Fig. 4. Female, 4th leg. $\times 173$

Fig. 5. Male, dorsal view. $\times 30$

Fig. 6. Male, abdomen, lateral view. $\times 60$

Fig. 7. Male, 2nd antenna. $\times \mathbf{1 7 3}$

Fgs. 1-12. Corycaeus (Agetus) limbatus G. Brady

Fig. 8. Female, dorsal view. $\times 30$

Fig. 9. Female, lateral view. $\times 30$

Fig. 10. Female, 2nd antenna. $\times 120$

Fig. 11. Male. dorsal view. $\times 45$

Fig. 12. Male, lateral view. $\times 45$

Figs. 13-16. Corycaeus (Urocorycaeus) longistylis Dana

Fig. 13. Female, dorsal view. $\times 30$

Fig. 14. Male, dorsal view. $\times 30$

Fig. 15. Male, 2nd antenna. $\times 120$

Fig, 16. Male, 4th leg. $\times 120$

\section{Plate 6.}

Figs. 1-12. Corycaeus (Urocorycaeus) lautus Dana

Fig. 1. Male, dorsal view. $\times 26$

Fig. 2. Male, 4th leg. $\times 120$

Figs. 3-6. Corycaeus (Urocorycaeus) furcifer Claus

Fig. 3. Female, dorsal view. $\times 30$

Fig. 4. Female, abdomen, lateral view. $\times 120$

Fig. 5. Female, 2nd antenna. $\times 120$

Fig. 6. Female, 4th leg. $\times 173$

Fig. 7-12. Corycaeus (Ditrichocorycaeus) andrewsi Farran

Fig. 7. Female, dorsal view. $\times 45$

Fig. 8. Female, abdomen, lateral view. $\times 120$

Fig. 9. Female, 2nd antenna. $\times 173$

Fig. 10. Male, dorsal view. $\times 60$

Fig. 11. Male, abdomen, lateral view. $\times 120$

Fig. 12. Male, 2nd antenna. $\times 240$

Figs. 13-19. Corycaeus (Ditrichocorycaeus) asiaticus F. Dahl

Fig. 13. Female, dorsal view. $\times 35$

Fig. 14. Female, abdomen, lateral view. $\times 70$

Fig. 15. Female, 2nd antenna. $\times 100$

Fig. 16. Female, apical spine of exopodite of 2nd leg. $\times 140$

Fig. 17. Female, 4th leg. $\times 150$

Fig. 18. Male, dorsal view. $\times 50$

Fig. 19. Male, abdomen, lateral view. $\times 100$ 
Plate 7.

Figs, 1-4. Corycaeus (Ditrichocorycaeus) subtilis M. DahI

Fig. 1. Female, lateral view. $\times 60$

Fig. 2. Female, abdomen, dorsal view. $\times 120$

Fig. 3, Female, 2nd antenna. $\times 240$

Fig. 4. Female, apical spine of exopodite of 2 nd leg. $\times 240$

Figs. 5-13. Corycaeus (Ditrichocorycaeus) dubius Farran

Fig. 5. Female, dorsal view. $\times 50$

Fig. 6. Female, abdomen, lateral view. $\times 50$

Fig. 7. Female, 2nd antenna. $\times 200$

Fig. 8. Female, apical spine of exopodite of 2 nd leg. $\times 200$

Fig. 9. Female, 4th leg. $\times 200$

Fig. 10. Male, dorsal view. $\times 60$

Fig. 11. Male, abdomen, lateral view. $\times 120$

Fig. 12. Male, 2nd antenna. $\times 240$

Fig. 13. Male, apical spine of exopodite of 1st leg. $\times 240$

Figs. 14-17. Corycaeus (Ditrichocorycaeus) dahli, nom. nov.

Fig. 14. Female, lateral view. $\times 50$

Fig. 15. Female, abdomen, dorsal view. $\times 70$

Fig. 16. Female, 2nd antenna. $\times 200$

Fig. 17. Female, apical spine of exopodite of 2nd leg viewed in two different aspects. $\times 200$

\section{Plate 8.}

Figs. 1-5. Corycaeus (Ditrichocorycaeus) dahli, sp. nov.

Fig. 1. Male, dorsal view. $\times 60$

Fig. 2. Male, abdomen, lateral view, $\times 120$

Fig. 3. Male, 2 nd antenna. $\times 240$

Fig. 4. Male, apical spine of exopodite of 2 nd leg. $\times 240$

Figs. 6-15. Corycaeus (Ditrichocorycaeus) affinis McMurrich

Fig. 6. Female, dorsal view. $\times 60$

Fig. 7. Female, abdomen, lateral view. $\times 120$

Fig. 8. Female, 2nd antenna. $\times 240$

Fig. 9. Female, apical spine of exopodite of 2 nd leg: $\times 200$

Fig. 10. Female, 4th leg. $\times 240$

Fig. 11. Male, dorsal view. $\times 60$

Fig. 12. Male, abdomen, lateral view. $\times 120$

Fig. 13. Male, 2nd antenna. $\times 240$

Fig. 14. Male, apical spine of exopodite of 1st leg. $\times 240$

Fig. 15. Male, 4th leg. $\times 40$

Figs. 16-18. Corycaeus (Onychocorycaeus) agilis Dana

Fig. 16. Female, dorsal view. $\times 60$

Fig. 17. Female, abdomen, lateral view. $\times 60$

Fig. 18. Female, 4th leg. $\times 240$ 
Plate 9.

Figs. 1-5. Corycaeus (Onychocorycaeus) agilis Dana

Fig. 1. Female, 2nd antenna. $\times 173$

Fig. 2. Male, dorsal view. $\times 60$

Fig. 3. Male, abdomen, lateral view. $\times 120$

Fig. 4. Male, abdomen, other specimen, lateral view. $\times 120$

Fig. 5. Male, 2nd antenna. $\times 240$

Figs. 6-12. Corycaeus (Onychocorycaeus) catus F. Dahl

Fig. 6. Female, lateral view. $\times 45$

Fig. 7. Female, abdomen, dorsal view. $\times 60$

Fig. 8. Female, 2nd antenna. $\times 173$

Fig. 9. Female, 4th leg. $\times 173$

Fig. 10. Male, dorsal view. $\times 60$

Fig. 11. Male, abdomen, lateral view. $\times 120$

Fig. 12. Male, apical spine of exopodite of 2nd leg. $\times 200$

Figs. 13-20. Corycaeus (Onychocorycaeus) pacificus F. Dahl

Fig. 13. Female, dorsal view. $\times 30$

Fig. 14. Female, abdomen, lateral view. $\times 45$

Fig. 15. Female, 2nd antenna. $\times 173$

Fig. 16. Female, 4 th leg. $\times 173$

Fig. 17. Female, apical spine of exopodite of 2nd leg. $\times 200$

Fig. 18. Male, abdomen, lateral view. $\times 60$

Fig. 19. Male, 2nd antenna. $\times 120$

\section{Plate 10.}

Figs. 1-5. Corycaens (Corycella) rostratus Claus

Fig. 1. Male, lateral view. $\times 83$

Fig. 2. Male, cephalothorax, dorsal view. $\times 120$

Fig. 3. Male, abdomen, ventral view. $\times 120$

Fig. 4. Male, 2nd antenna. $\times 240$

Fig. 5. Male, 4th leg. $\times 353$

Figs. 6-11. Corycaeus (Corycella) gibbulus Giesbrecht

Fig. 6. Female, lateral view. $\times 45$

Fig. 7. Female, abdomen, ventral view, $\times 60$

Fig. 8. Female, 2nd antenna. $\times 240$

Fig. 6. Male, dorsal view. $\times 60$

Fig. 10. Male, abdomen, lateral view. $\times 120$

Fig. 11. Male, 2nd antenna. $\times 240$

Figs. 12-16. Corycaeus (Corycella) concinnus Dana

Fig. 12. Female, dorsal view. $\times 60$

Fig. 13. Female, lateral view. $\times 60$

Fig. 14. Female, 2nd antenna. $\times 240$

Fig. 15. Male, dorsal view. $\times 60$

Fig. 16. Male, abdomen, lateral view. $\times 120$ 
Jour. Fac. Agric., Kyushu Univ., Vol. 11

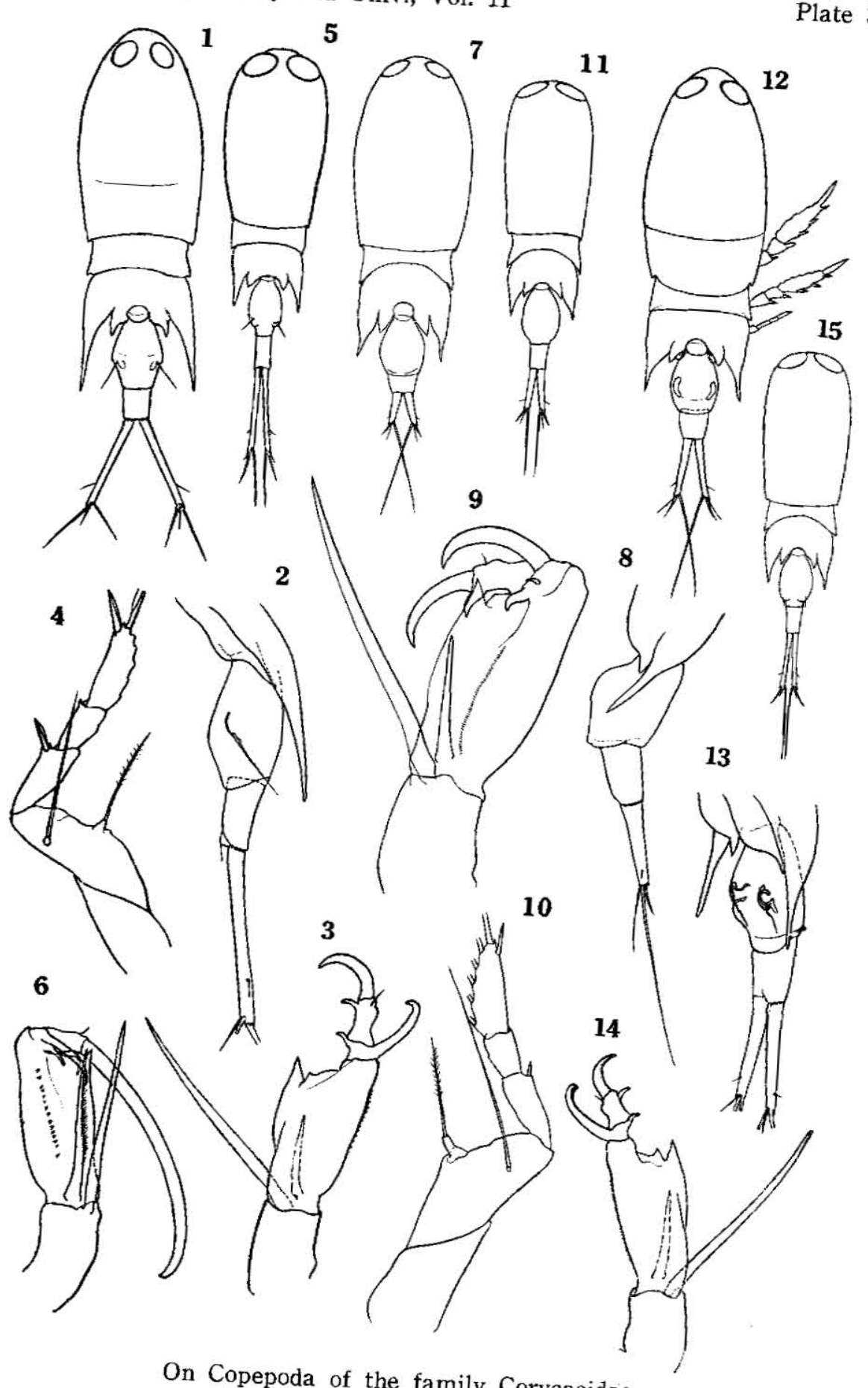




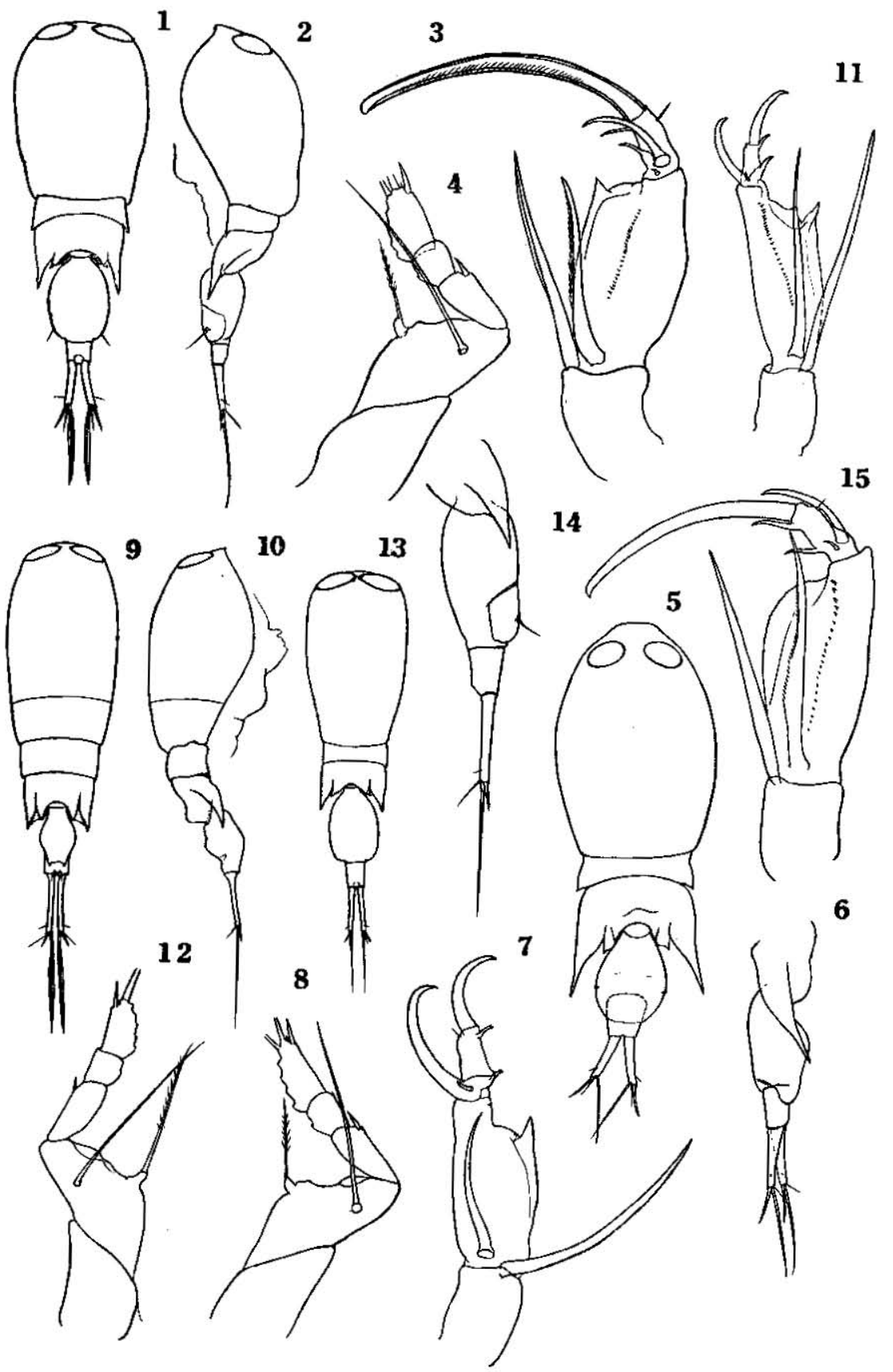

On Copepoda of the family Corycaeidae 
Jour. Fac. Agric., Kyushu Univ., Vol. 11

Plate 5

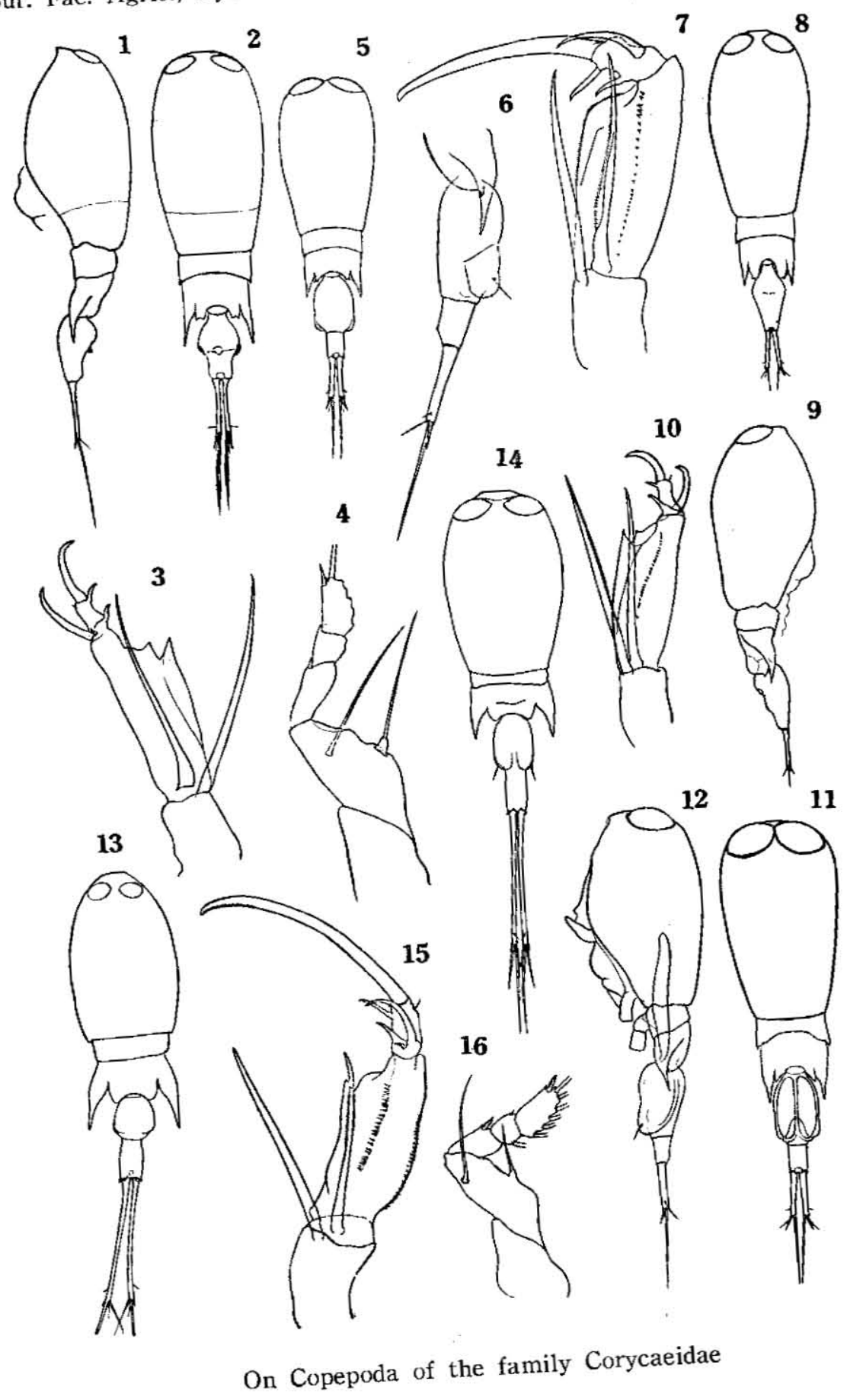


Jour. Fac. Agric., Kyushu Univ., Vol. 11

Plate 6

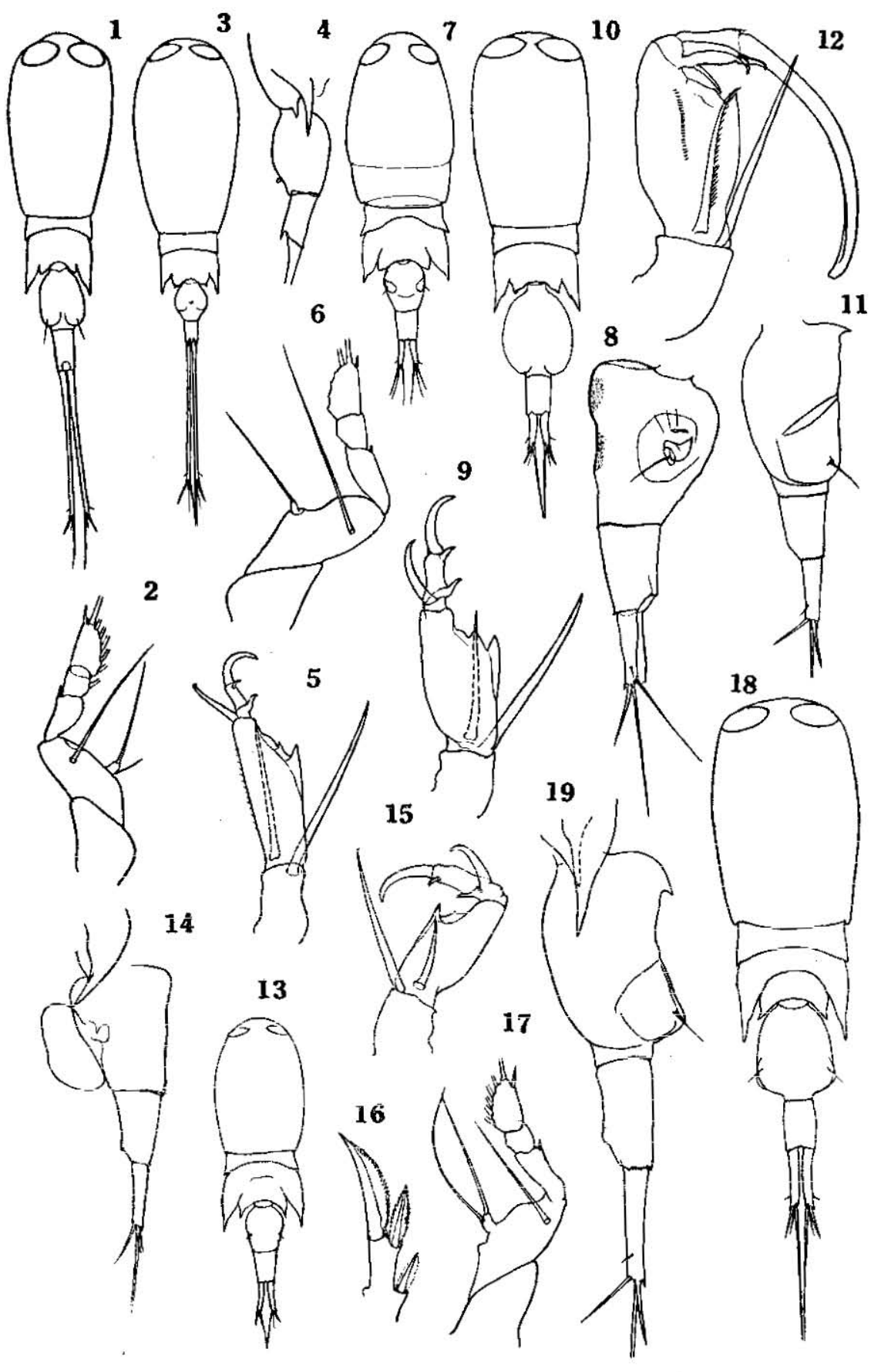

On Copepoda of the family Corycaeidae 
Jour. Fac. Agric., Kyushu Univ., Vol. 11

Plate 7

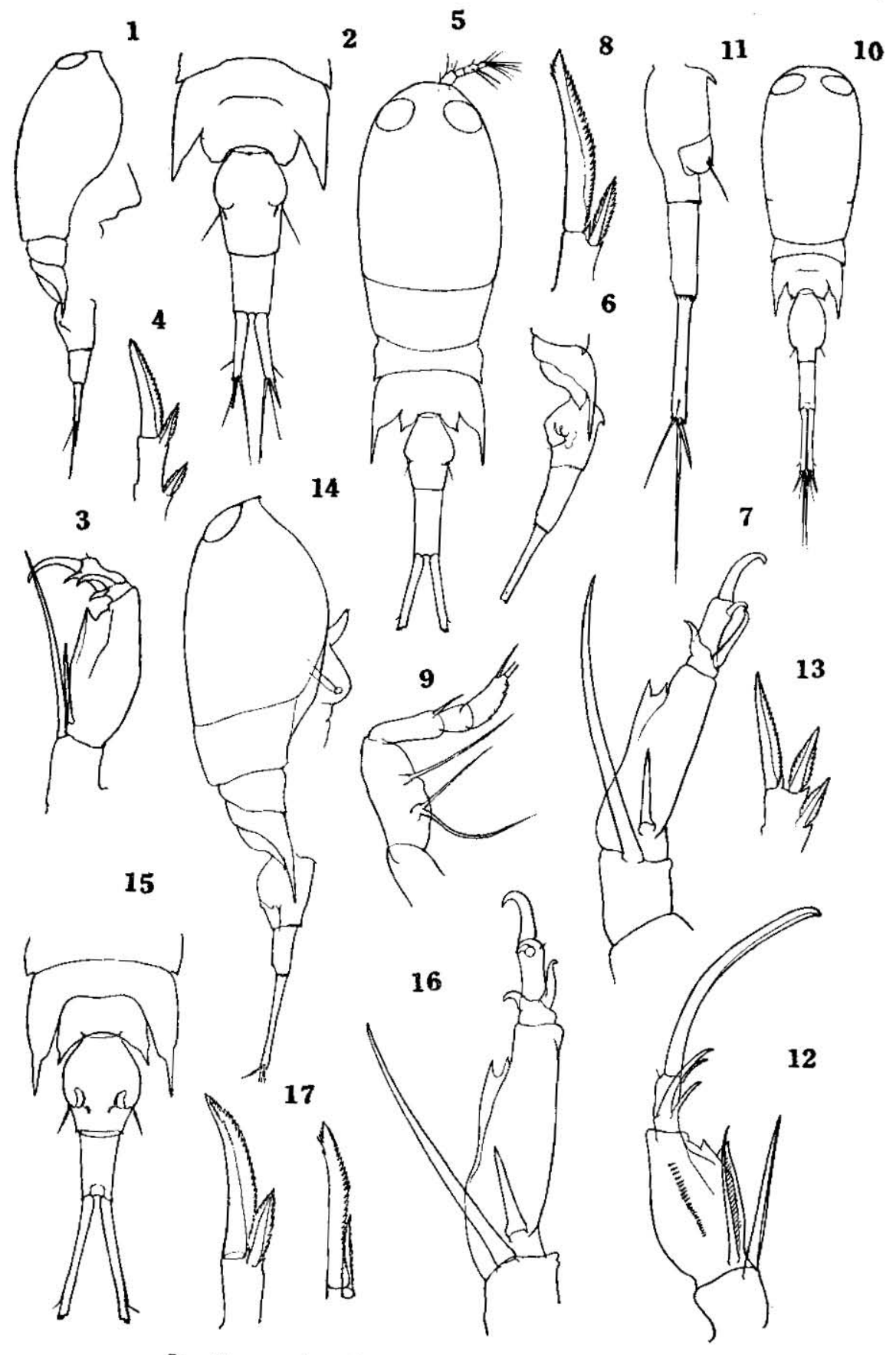

On Copepoda of the family Corycaeidae 
Jour. Fac. Agric., Kyushu Univ., Vol. 11

Plate 8

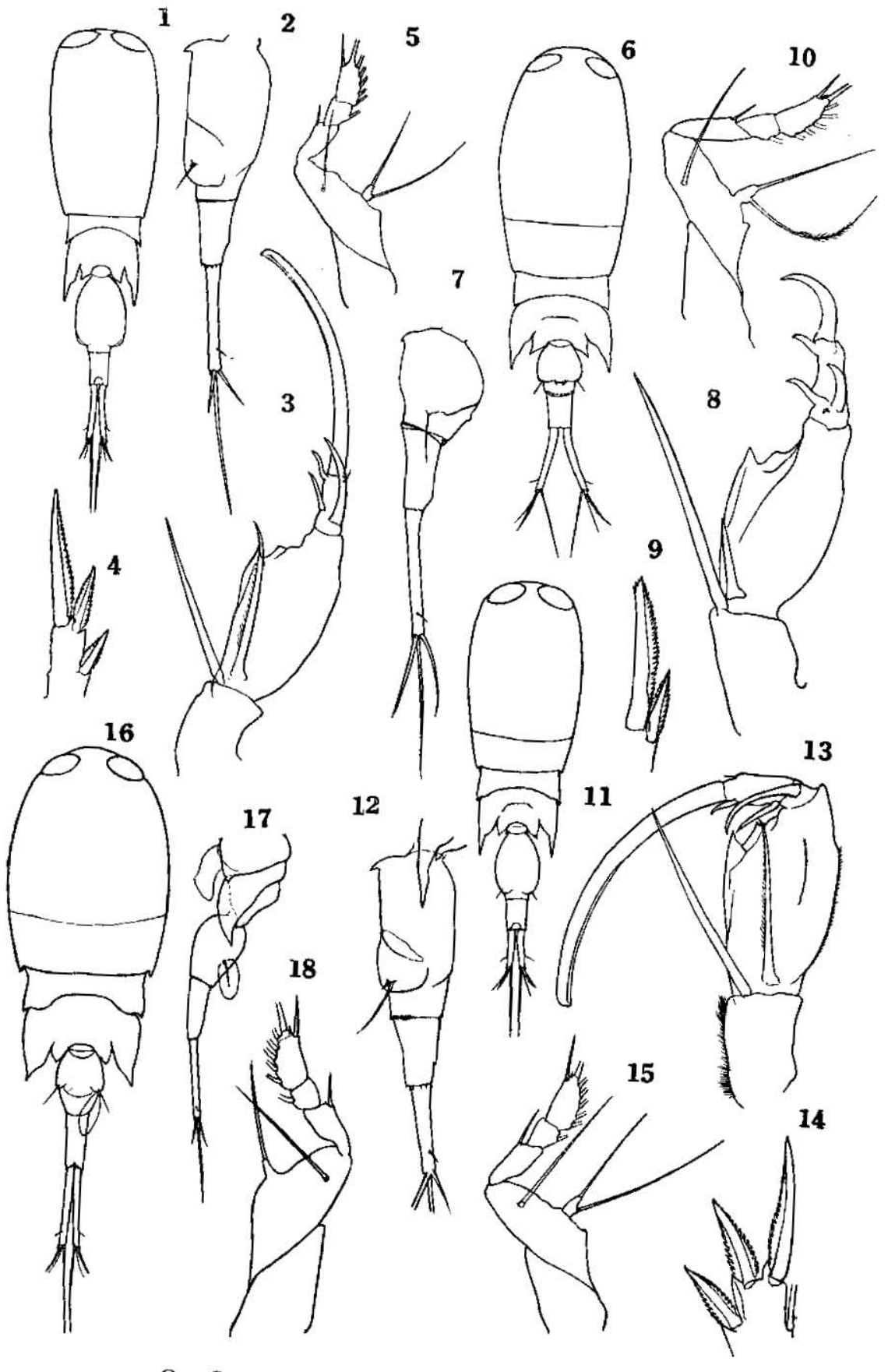

On Copepoda of the family Corycaeidae 


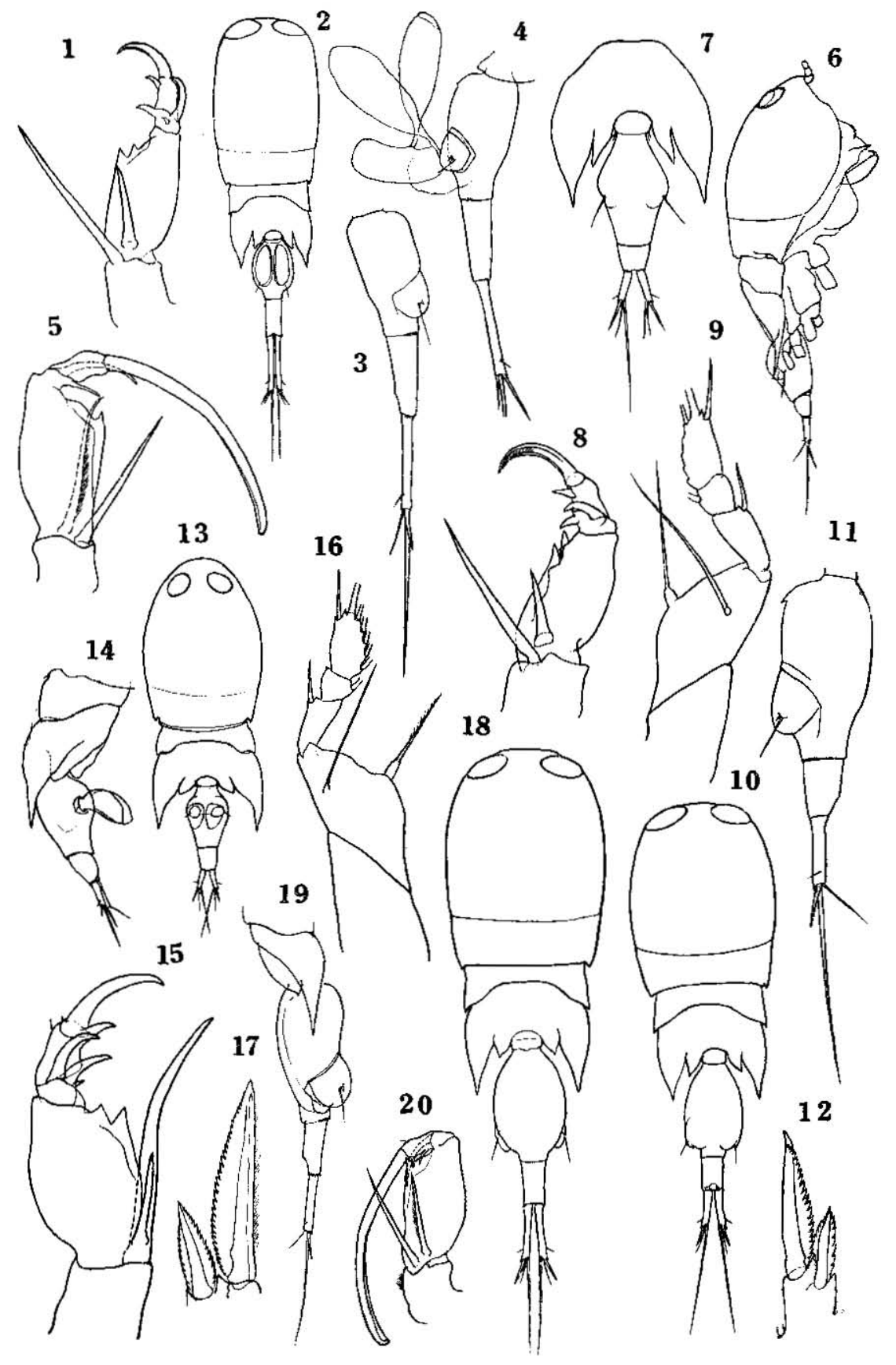

On Copepoda of the family Corycaeidae 
Jour. Fac. Agric., Kyushu Univ., Vol. 11

Plate 10

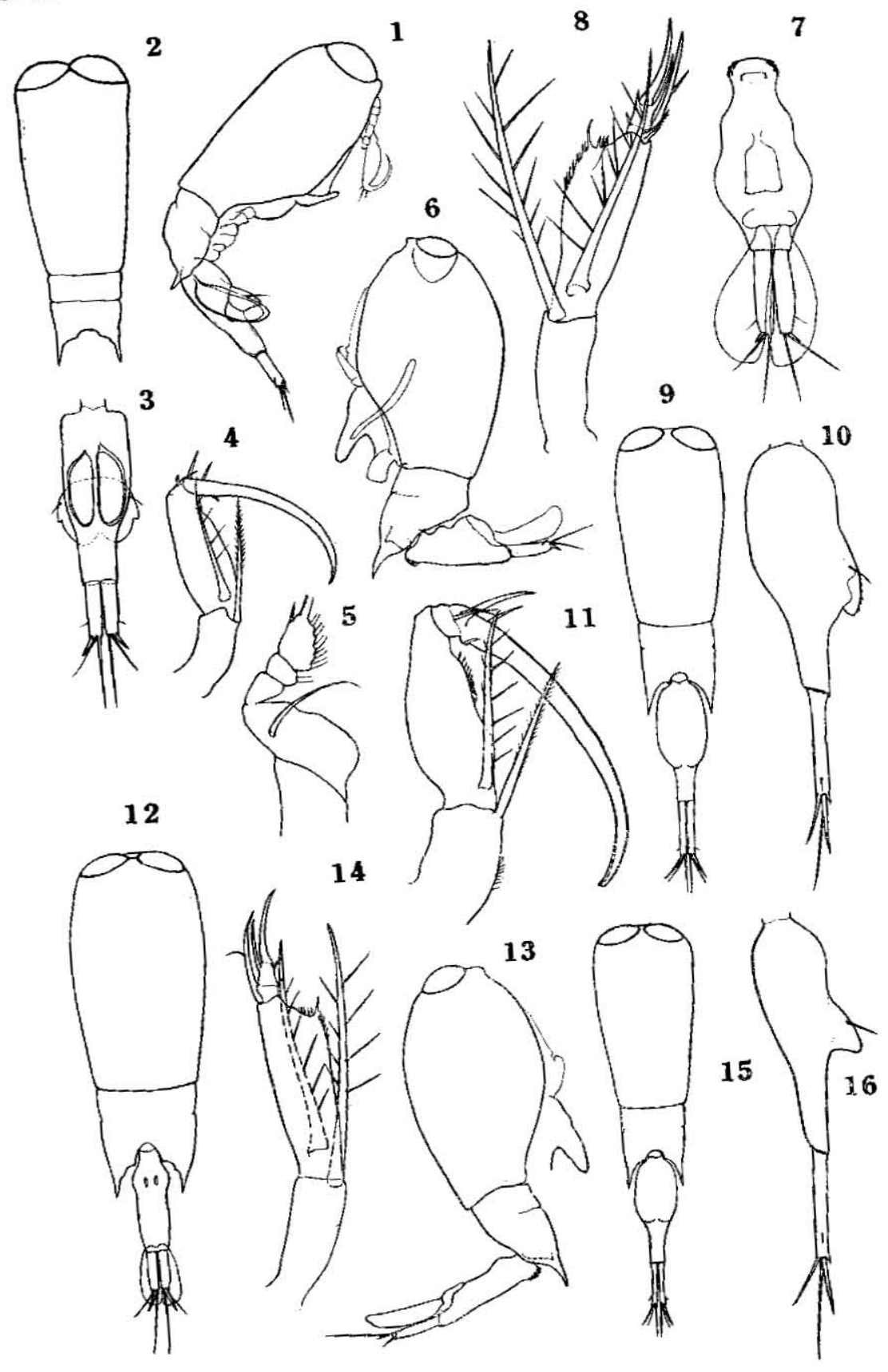

On Copepoda of the family Corycaeidae 